\title{
PERTUMBUHAN EKONOMI TAK BERKUALITAS DAN PERLUNYA KEBIJAKAN PEMERINTAH DALAM PERLUASAN KESEMPATAN KERJA DI KOTA MAKASSAR
}

\author{
Burhanuddin \\ Pascasarjana Universitas Negeri Makassar
}

\begin{abstract}
ABSTRAK
Penelitian sederhana ini bertujuan menguraikan konsepsi pertumbuhan ekonomi tidak berkualitas dan akibatnya di Kota Makassar serta mencari solusi kebijakan apa yang hendaknya dilakukan untuk mengatasinya. Tulisan ini menggunakan pendekatan ekonomi politik klasik dan neo klasik yang juga merupakan bagian dari ilmu administrasi khususnya ilmu administrasi yang berkonsentrasi pada masalah pembangunan. Adapun penelitian ini adalah penelitian pustaka, dimana metode studi dokumentasi adalah satu satunya metode yang digunakan. Teknik analisis data lebih bersifat deskriptif dimana hasil penelitian diuraikan secara kualitatif sehingga diperoleh gambaran mengenai masalah pertumbuhan ekonomi tak berkualitas dan sekaligus ingin menunjukkan diperlukan kebijakan - kebijakan pemerintah baik terobosan ataupun intensifikasi kebijakan yang ada guna mengurangi pengangguran, kemiskinan dan mengurangi trend informalisasi ekonomi. Periode waktu data yang digunakan mulai 2005 hingga 2010.
\end{abstract}

Kata Kunci: Pertumbuhan ekonomi tak berkualitas, kebijakan pemerintah, pengangguran, kemiskinan dan informalisasi ekonomi.

\section{PENDAHULUAN}

Substansi ekonomi politik yang juga menjadi pokok perhatian administrasi antara lain berupa persoalan keterbelakangan, pertumbuhan, perkembangan, pembangunan ekonomi sosial, sistem-sistem ekonomi, realisme dan idealisme, linear dan strukturalis internasional dan sebagainya. Dalam pendekatan ekonomi politik, masalah yang dihadapi antara lain mencakup variabelvariabel politik, variabel ekonomi, variabel sosial budaya, sedangkan faktor-faktor yang berpengaruh meliputi (1) intervensi pemerintah, perubahan kebijakan, tindakan politik ekonomi, (2) kenaikan harga di pasar, (3) kemerosotan daya beli masyarakat, (4) kelangkaan sumber daya, (5) revolusi sosial, transformasi industrial, (6) revolusi dan kemajuan ilmu, pengetahuan, teknologi, komunikasi, dan informasi ( Caporaso dan Levine :2008).

Dalam kehidupan suatu negara sering terjadi berbagai permasalahan. Negara yang memegang penuh tanggung jawab pada kehidupan rakyatnya harus mampu menyelesaikan permasalahanpermasalahan tersebut. Kebijakan publik yang dibuat dan dikeluarkan oleh negara diharapkan dapat menjadi solusi akan permasalahan tersebut. Kebijakan publik merupakan keputusan yang dibuat oleh pemerintah untuk melakukan pilihan tindakan tertentu untuk tidak melakukan sesuatu maupun untuk melakukan tidakan tertentu(Mustopadidjaja, 2002).

Kesejahteraan yang dilandasi kepemilikan pekerjaan dan tidak terkategorikan dalam kemiskinan dan ketertinggalan merupakan keinginan setiap penduduk suatu negara karena itu, sejak berdirinya Republik Indonesia, melalui 
UUD 1945 telah mengamanatkan bahwa negara wajib memenuhi kebutuhan masyarakat dalam mendapatkan pekerjaan dan penghidupan yang layak bagi kemanusiaan. Kewajiban dimaksud mencakup kewajiban menjamin ketersediaan, keterjangkauan, dan pemenuhan secara adil dan merata. Untuk bisa melaksanakan kewajiban tersebut secara efektif, maka negara wajib menyediakan lapangan pekerjaan utamanya di sektor formal karena diktum pekerjaan dan penghidupan yang layak bagi kemanusiaan tersebut.

\section{KAJIAN TEORI}

\section{Ekonomi Politik Pembangunan}

Ekonomi politik setidaknya dipahami sebagai sebuah kebijakan negara atau publik dalam ranah interaksi negara dan pasar. Dalam dimensi ini dapat diartikan bagaimana sebuah pemerintahan dalam sebuah negara mempengaruhi ranah ekonomi atau sebaliknya bagaimana ekonomi atau pasar mempengaruhi negara dalam kebijakannya. Substansinya antara lain berupa persoalan keterbelakangan, pertumbuhan, perkembangan, pembangunan ekonomi sosial, sistemsistem ekonomi, realisme dan idealisme, linear dan strukturalis internasional, globalisasi, regionalisme, dan sebagainya.

Deliarnov (2006) menyatakan baik dalam teori ekonomi politik klasik maupun dalam ekonomi politik kontemporer digambarkan adanya hubungan di antara ekonomi dan politik dalam suatu negara. Dalam teori ekonomi politik klasik dinyatakan bahwa pasar memiliki kemampuan untuk mengelola dirinya sendiri. Pandangan seperti ini seringkali dijadikan sebagai dasar dalam menjalankan kebijakan pasar bebas. Bahkan para ekonom klasik ini adalah yang pertama kalinya memandang perekonomian sebagai sebuah sistem yang secara prinsip terpisah dari politik dan rumah tangga. Para ekonom klasik tetap menganggap bahwa politik sebagai sesuatu yang penting, namun tindakan-tindakan yang terkait dengan politik jangan terus-menerus mengintervensi pasar, biarkan pasar berjalan apa adanya sehingga keuntungan akan diperoleh dari pasar yang bekerja secara alami ini. Apabila mekanisme pasar bekerja secara alami - dimana perekonomian diserahkan kepada pasar tanpa intervensi politik - maka akan berdampak pada tumbuh dan berkembangnya perekonomian secara makro. Teori ekonomi klasik berpendapat bahwa peran pemerintah sebenarnya terbatas hanya pada masalah penegakan hukum, menjaga keamanan dan pembangunan infrastruktur. Campur tangan negara baru diperlukan manakala tidak ditemukan adanya keseimbangan atau kesempurnaan pasar. Pasar yang sempurna ditentukan oleh permintaan dan penawaran itu sendiri.

\section{Pendekatan Neo Klasik Dalam Ekonomi Politik}

Pemikiran yang membahas campur tangan negara (politik) yang bersifat sementara dalam menciptakan keseimbangan atau kesempurnaan pasar dilanjutkan dalam pendekatan neo klasik. Pasar yang sempurna ditentukan oleh tarikmenarik antara penawaran dan permintaan.

Salahsatu teori neoklasik adalah teori Harrold-Domar. Teori ini menekankan konsep tingkat pertumbuhan natural.selain kuntitas faktor produksi tenaga kerja, diperhitungkan juga kenaikan efisiensi pendidikan dan latihan. Teori ini dapat menentukan berapa besarnya tabungan atau investasi yang diperlukan untuk memelihara tingkat laju pertumbuhan ekonomi natural yaitu angka maju pertumbuhan ekonomi natural dikalikan dengan kapital-output. Menurutnya pertumbuhan ekonomi adalah peningkatan produksi Nasional dan Regional secara fisik, atau dalam istilah umum adalah peningkatan produk domestic bruto atau produk domestic regional bruto. PDB atau PDRB adalah 
jumlah barang dan jasa yang dihasilkan oleh suatu perekonomian Negara atau daerah dalam waktu satu huruf. Atau dengan kata lain pertumbuhan ekonomi adalah proses dimana terjadi kenaikan produk nasional bruto riil atau pendapatan nasional riil. Jadi perekonomian dikatakan tumbuh atau berkembang bila terjadi pertumbuhan output riil definisi pertumbuhan ekonomi yang lain adalah bahwa pertumbuhan ekonomi terjadi bila ada kenaikan output perkapita. Pertumbuhan ekonomi menggambarkan kenaikan taraf hidup diukur dengan output riil per orang. Salah satu cara untuk melihat kemajuan perekonomian suatu daerah adalah dengan mencermati nilai Produk Domestik Regional Bruto (PDRB). PDRB merupakan nilai dari seluruh barang dan jasa yang diproduksi dalam jangka waktu tertentu biasanya dalam waktu satu tahun. Dalam menghitung pendapatan regional hanya dipakai konsep domestik. Berarti seluruh nilai tambah ditimbulkan oleh berbagai sektor atau lapangan usaha yang melakukan kegiatan usahanya di suatu wilayah atau region (propinsi atau kabupaten) dimasukkan tanpa memperhatikan kepemilikan faktor-faktor produksi.

\section{Hubungan Pertumbuhan Ekonomi Dan Penyerapan Tenaga Kerja}

Dalam teori neo klasik dikatakan tingginya kesempatan kerja akan berpengaruh terhadap pencapaian ekonomi dari suatu negara. Alasanya, kerena kegiatan ekonomi masyarakat ditunjukkan dengan kinerja produksi masyarakat yang baisanya dicerminkan oleh Produk Domestik Bruto (PDB), sedangkan untuk daerah yaitu produk Domestik Regional Bruto (PDRB). Pemecahan masalah kesempatan kerja dapat ditempuh antara lain dengan menciptakan lapangan kerja produktif dan perluasan kesempatan kerja yang dilaksanakan dengan mengadakan kegiatan-kegiatan ekonomi diberbagai sektor yang disertai dengan usaha peningkatan produktivitas angkatan kerja yang ada.

Pembangunan ekonomi pada hakekatnya merupakan suatu proses yang berkesinambungan antara sektor ekonomi sehingga dengan terciptanya pertumbuhan ekonomi dapat menciptaakan lapangan kerja, pemerataan pendapatan dan pada akhirnya meningkatkan taraf hidup masyarakat. Dalam suatu proses pembangunan ekonomi mencakup aktifitas ekonomi yang mengupayakan pengoptimalan penggunaan faktor-faktor ekonomi yang tersedia sehingga menciptakan nilai ekonomis, salah satu faktor ekonomi yang dimaksud adalah tenaga kerja.

Dudley Seers, mengemukakan bahwa tolak ukur pembangunan ekonomi tidak saja pada peningkatan pendapatan perkapita tetapi hendaknya juga disertai oleh baiknya distribusi pendapatan, menurunnya angka kemiskinan dan pengangguran. Dari uraian tersebut dapat disimpulkan bahwa masalah yang paling mendasar dalam ketenagakerjaan dan pembangunan ekonomi adalah supplydemand dalam pasar tenaga kerja. Sedangkan Kuznets menjabarkan adanya trade off antara pertumbuhan ekonomi dengan distribusi yang merata dalam pendapatan perkapita. Kuznets juga menekankan bahwa untuk mengukur formasi modal adalah tidak tepat dan tidak efisien bila hanya kepada modal fisik dan modal tetap lainya. Namun, Kuznets menyatakan bahwa sektor tradisional atau atau juga sektor pertanian memiliki peranan yang cukup besar dalam proses pembangunan teritama dalam hal menyerap tenaga kerja.

Menurut Todaro (1999) ada tiga faktor atau komponen utama yang berpengaruh dalam pertumbuhan ekonomi suatu daerah, ketiganya adalah akumulasi modal, pertumbuhan penduduk dan kemajuan teknologi. Akumulasi modal meliputi semua jenis investasi baru baik yang dilakukan oleh pemerintah ataupun swasta yang ditanamkan dengan bentuk 
tanah, peralatan fisik, dan modal sumber daya. Akumulasi modal akan terjadi apabila sebagian dari pendapatan ditabungkan (diinvestasikan) kembali dengan tujuan untuk memperbesar output atau pendapatan di kemudian hari. Keberhasilan daerah untuk meningkatkan daya tariknya terhadap investasi salah satunya tergantung dari kemampuan daerah dalam merumuskan kebijakan yang berkaitan dengan investasi dan dunia usaha serta peningkatan kualitas pelayanan terhadap masyarakat. Investasi dengan karakteristik seperti ini, bersifat nirlaba atau non profit motif, seperti pembangunan jalan dan jembatan, sekolah, taman, pasar, rumah sakit, dan sarana serta prasarana publik lainnya. Karena investasi ini dilakukan oleh negara, maka pembiayaannya dilakukan melalui Anggaran Pendapatan Dan belanja Negara (APBN) atau anggaran pendapatan daerah (APBD). Investasi publik ini menghasilkan nilai tambah berupa barang dan jasa, lapangan pekerjaan, sewa dan bunga, tanpa surplus usaha maupun investasi swasta yang merupakan investasi yang dilakukan oleh swasta, dengan tujuan mendapat manfaat berupa laba.

\section{Pertumbuhan Ekonomi Tak Berkualitas}

Jika pertumbuhan ekonomi yang baik atau berkualitas ditandai dengan linearitas antara pertumbuhan ekonomi dengan penyerapan tenaga kerja utamanya di sektor formal dan ditopang perkembangan sektor rill maka sebaliknya Robinson Tarigan (2008) dan Yustika (2011) menjelaskan pertumbuhan ekonomi tak berkualitas dicirikan pertama, pertumbuhan ekonomi di sektor riil (pertanian, pertambangan dan industri) tetap berada dalam zona rendah atau terjebak dalam zona pertumbuhan rendah, di sisi lain tenaga banyak yang terserap di sektor tersebut akibatnya kemiskinan dan pengangguran tidak bisa dikurangi, pertumbuhan yang rendah belum mampu mendorong terbukanya kesempatan kerja baru secara signifikan. Di sektor - sektor tersebut itulah kantong kemiskinan berada (petani, nelayan, buruh). Dengan kata lain selama sektor riil terjebak dalam pertumbuhan rendah, maka masalah kemiskinan dan pengangguran sulit diatasi. Kedua, sektor non-tradeable bergerak cepat dan menjadi sumber terpenting pertumbuhan ekonomi. Dalam penyerapan tenaga kerja, sektor telekomunikasi, konstruksi, dan keuangan kira-kira menyumbang tenaga kerja yang banyak. Ketiga, sektor manufaktur mengalami gejala penurunan (deindustrialisasi). Jika pertumbuhan dan kontribusi sektor industri rendah, daya saing, nilai tambah, dan diversifikasi komoditas perekonomian nasional dipastikan bakal keropos. Keempat, pertumbuhan ekonomi tak berkualitas salahsatunya juga diperlihatkan pada informalisasi ekonomi. Maksudnya, kegiatan ekonomi disesaki dengan pelaku sektor informal, termasuk tenaga kerja yang terlibat di dalamnya. Kelima, sebagai faktor pendukung adalah lemahnya APBN/D dalam menciptakan kesempatan kerja dengan kata lain APBN/D tidak bisa banyak diharapkan.

\section{METODE PENELITIAN}

Jenis penelitian ini adalah deskriptif dengan pendekatan kualitatif. Adapun sumber data diperoleh dari hasil studi pustaka/literatur. Sedangkan studi dokumentasi adalah satu - satunya metode yang digunakan. Studi dokumen, yang dimaksud penelaahan buku dan jurnal yang berhubungan dengan ekonomi politik dan ekonomi pembangunan, dokumen statistik dan perencanaan daerah, dokumen dinas tenaga kerja. Serta dokumen lain yang dianggap penting untuk menjawab penelitian. Dalam penelitian ini, data dianalisis secara deskriptif. Hasil penelitian akan diterjemahkan dan diuraikan secara kualitatif sehingga diperoleh gambaran mengenai masalah yang muncul akibat pertumbuhan ekonomi tak berkualitas, penyerapan tenaga kerja dan pemerataan dan informalisasi ekonomi 
serta solusi kebijakan yang dianggap bisa memberikan jalan keluar terhadap permasalahan yang ada.

\section{HASIL DAN PEMBAHASAN}

\section{Pertumbuhan Ekonomi Indonesia: Pertumbuhan Tak Berkualitas}

Ahmad Erani Yustika (2010) menyatakan Terdapat tiga catatan penting dari struktur pertumbuhan ekonomi Indonesia sampai 2010. Pertama, pertumbuhan ekonomi di sektor riil tetap berada dalam zona rendah (di bawah $5 \%$ ) sehingga menimbulkan komplikasi persoalan yang tidak terpecahkan dalam sejarah modern ekonomi nasional, yakni kemiskinan dan pengangguran. Sampai 2009, sektor pertanian (perkebunan, kehutanan, dan perikanan) menyumbang sekitar $41 \%$ tenaga kerja, sedangkan sektor industri pengolahan menyerap sekitar $12 \%$ tenaga kerja. Jadi, kedua sektor tersebut menyerap lebih dari 50\% dari total tenaga kerja di Indonesia. Jika kedua sektor tersebut terjebak dalam zona pertumbuhan rendah, maka masalah kemiskinan dan pengangguran tidak akan bisa dikurangi secara meyakinkan. Sebabnya, dikedua sektor itulah kantong-kantong kemiskinan berada (petani, nelayan, buruh). Demikian pula, bila kedua sektor itu tumbuh rendah, kemampuannya menciptakan lapangan kerja juga sangat terbatas. Kedua, sektor non-tradeable selama beberapa tahun terakhir justru bergerak cepat dan menjadi sumber terpenting pertumbuhan ekonomi. Dalam peta penyerapan tenaga kerja, sektor telekomunikasi, konstruksi, dan keuangan kira-kira menyumbang 11,5\% tenaga kerja. Dengan pertumbuhan ekonomi yang konsisten di atas rata-rata pertumbuhan ekonomi nasional, maka sektor tersebut menikmati kemakmuran ekonomi yang lebih besar ketimbang sektor lainnya. Implikasinya, tenaga kerja yang terlibat di dalamnya memeroleh penghasilan yang lebih besar. Tentu saja fakta ini meniupkan masalah berikutnya, yakni munculnya intensitas ketimpangan pendapatan yang lebih besar antarsektor ekonomi (juga ketimpangan pendapatan antarpelaku dan antarwilayah). Tanpa disadari pula, ketimpangan pertumbuhan ekonomi antara sektor tradeable dan nontradeable bakal menjadi sumber persoalan ekonomi yang akut, bahkan menjalar ke masalah sosial dan politik dikemudian hari. Tenaga kerja di Indonesia menumpuk di tradeable sector, di mana untuk sektor pertanian dan industri sudah menyerap tenaga kerja sekitar 52\% dari total tenaga kerja. Deskripsi ini dengan mudah menerbitkan kesimpulan bahwa selama sektor riil terjebak dalam pertumbuhan rendah, maka masalah kemiskinan dan pengangguran sulit diatasi. Ketiga, daya saing, nilai tambah, dan diversifikasi komoditas perekonomian nasional dipastikan bakal keropos karena sektor manufaktur mengalami gejala penurunan (deindustrialisasi). Jika pertumbuhan dan kontribusi sektor industri rendah, maka hal itu menunjukkan ketiadaan strategi untuk meningkatkan nilai tambah terhadap produk yang dihasilkan. Contoh sederhana, saat ini Indonesia merupakan eksportir besar di dunia untuk beberapa komoditas, seperti kelapa sawit, ikan tuna, dan batubara. Namun, nilai dari produk tersebut sangat murah di pasar internasional dibandingkan apabila produk tersebut diolah terlebih dulu di dalam negeri. Hal ini yang menyebabkan Indonesia tidak bisa memaksimalisasikan pertumbuhan ekonomi karena hanya menghasilkan produk primer.

\section{Kinerja Pertumbuhan Ekonomi Kota Makassar \\ Perekonomian Kota Makassar dari tahun ke tahun terus menunjukkan perkembangan yang cukup dinamis. Selama kurun waktu 2006-2007, nilai PDRB Atas Dasar Harga berlaku (ADH) meningkat dari Rp. 1.058,54 milyar pada tahun 2006 menjadi Rp. 1.254,49 milyar pada tahun 2007 atau naik sebesar Rp.}


195,95 milyar. Sementara nilai PDRB ADH konstan tahun 2000 sebesar Rp. 586,32 milyar pada tahun 2007 atau naik sebesar Rp. 42,49 milyar dibandingkan tahun 2006 yang hanya mencapai Rp. 543,83 milyar.

Dilihat berdasarkan laju pertumbuhannya, PDRB ADH konstan tahun 2000 selama kurun waktu 2006-2007 (y.o.y) masing-masing tumbuh sebesar $7,35 \%$ dan $7,81 \%$. Nilai yang serupa juga diperlihatkan oleh laju pertumbuhan ekonomi atau laju pertumbuhan PDRB ADH konstan tahun 2000 kuartal terhadap kuartal (q.o.q). Angka tersebut adalah lebih tinggi apabila dibandingkan laju pertumbuhan ekonomi nasional yang hanya mencapai $5,50 \%$ dan $6,30 \%$ dalam kurun waktu yang sama. Sementara dari kuartal ke kuartal (q.t.q), laju pertumbuhan ekonomi Kota Makassar berada di atas angka $1,70 \%$ selama kurun waktu 20062007.

Secara sektoral, tingginya laju pertumbuhan ekonomi Kota Makassar selam kurun waktu 2006-2007 tidak terlepas dari kinerja sektor-sektor pembentuknya yang mengalami pertumbuhan positif, kecuali sektor pertambangan dan penggalian yang mengalami kontraksi sebesar 7,89\%. Sektor listrik, gas dan air bersih tercatat sebagai yang paling tinggi mengalami peningkatan tertinggi pada tahun 2007 dengan laju pertumbuhan sebesar $44,63 \%$ atau meningkat $35,29 \%$ dibandingkan tahun 2006. Tingginya laju pertumbuhan sektor tersebut menunjukkan bahwa kebutuhan pelaku ekonomi di Kota Makassar akan listrik terus meningkat seiring dengan makin berkembangnya perekonomian Kota Makassar. Salah satu indikasi tersebut dibuktikan dengan laju pertumbuhan sektor industri pengolahan, khususnya sub-sektor industri tanpa migas sebesar $11,01 \%$ atau meningkat $4,74 \%$ dibandingkan tahun 2006.

Seiring dengan meningkatnya pembangunan fisik, seperti rumah toko, menempatkan sektor konstruksi/bangunan sebagai sektor kedua yang mengalami pertumbuhan tertinggi pada tahun 2007 dengan laju pertumbuhan sebesar $12,25 \%$ atau meningkat $2,51 \%$ dibandingkan tahun 2006. Selanjutnya, meskipun pada tahun 2007 laju pertumbuhan sektor keuangan, persewaan bangunan dan jasa perusahaan mengalami penurunan sebesar 13,54\% dibandingkan tahun 2006, akan tetapi secara umum laju pertumbuhan sektor tersebut cukup tinggi, yaitu mencapai $9,25 \%$. Relatif tingginya laju pertumbuhan sektor ini adalah tidak terlepas dari makin berkembang sub-sektor keuangan dan lembaga keuangan lainnya. Salah satunya adalah beroperasinya bank berskala nasional seperti Bank Mualamat dan Bank Panin di Kota Makassar.

Pada tahun 2008, laju pertumbuhan ekonomi Kota Makassar sebesar 7,02\% atau menurun $0,79 \%$ dibandingkan tahun 2007. Penurunan tersebut, secara sektoral dapat dilihat dengan lebih rendah laju pertumbuhan ekonomi kuartalan (q.t.q) pada tahun 2008 yang hanya berkisar 1,62\%-1,68\%, sementara pada tahun 2007 berkisar antara 1,80\%-2,26\%. Selain itu, meskipun semua sektor pembentuk PDRB ADH konstan tahun 2000 Kota Makassar pada tahun 2008 mengalami pertumbuhan secara positif, akan tetapi sektor-sektor ekonomi yang berkontribusi besar seperti sektor perdagangan, hotel dan restoran serta sektor jasa-jasa lebih rendah laju pertumbuhan dibandingkan tahun 2007. Sektor-sektor yang mengalami laju pertumbuhan lebih rendah pada tahun 2008 adalah sektor listrik, gas dan air bersih serta sektor keuangan, persewaan bangunan dan jasa perusahaan.

Adapun struktur ekonomi Kota Makassar yang direfleksikan oleh kontribusi sektor-sektor pembentuk PDRB Atas Dasar Harga (ADH) berlaku sampai tahun 2007 masih didomiansi oleh sektorsektor yang masuk dalam kelompok tersier $(63,33 \%)$ sementara kelompok primer dan sekunder masing-masing hanya sebesar 17,37\% dan 19,30\%. Pada tahun 2007, sektor yang paling berpengaruh terhadap 
pembentukan PDRB adalah sektor perdagangan, hotel dan restoran yang kemudian diikuti oleh sektor jasa-jasa dan sektor pertanian. Ketiga sektor tersebut masing-masing memberikan kontribusi sebesar 24,24\% (Rp. 304,13 milyar), $21,91 \%$ (Rp. 274,91 milyar) dan 16,96\% (Rp. 212,76 milyar) .Fenomena yang hampir sama, tetap berlanjut pada tahun 2008, tetapi diperkirakan peranan dari sektor perdagangan, hotel dan restoran lebih tinggi dibandingkan dengan sektorsektor lainnya. Selain itu, sektor pengangkutan dan komunikasi serta sektor konstruksi/bangunan terus menunjukkan konsistensi sebagai kandidat sektor unggulan Kota Makassar di masa yang akan datang.

\section{Pertumbuhan Ekonomi Kota Makassar: Pertumbuhan Ekonomi Tak Berkualitas}

Terdapat beberapa fakta yang menunjukkan pertumbuhan ekonomi Kota Makassar 2005 - 2009 adalah pertumbuhan tak berkualitas. Pertama, selama kurun waktu 2005-2009, laju pertumbuhan ekonomi Kota Makassar ratarata $7,70 \%$, akan tetapi hal tersebut belum mampu mendorong terbukanya kesempatan kerja baru secara signifikan. Berdasarkan data yang dikeluarkan oleh BPS Kota Makassar (2008), menurunnya tingkat pengangguran pada tahun 2007 dibandingkan tahun 2006 terutama disebabkan oleh menurunnya jumlah penduduk usia 15 tahun ke atas yang masuk dalam kategori angkatan kerja dan pada sisi lain, penduduk yang masuk kategori bukan angkatan kerja meningkat. Selain itu, ternyata pada tahun 2006 angka setengah pengangguran atau angkatan kerja yang bekerja kurang dari 35 jam adalah sekitar 15.227 orang. Selaras dengan hal tersebut, jumlah penduduk miskin terus meningkat. Pada tahun 2007 penduduk Kota Makassar yang berada dibawah garis kemiskinan sekitar 56.034 jiwa $(44,97 \%$ dari keseluruhan jumlah penduduk) dan yang miskin sekitar 32.432 jiwa $(26,03 \%$ dari keseluruhan jumlah penduduk) atau masing-masing meningkat sebesar $12,55 \%$ dan 9,79\% dibandingkan tahun 2006. Dengan kata lain, pada tahun 2007 jumlah total penduduk miskin di Kota Makassar mencapai 88.466 jiwa atau meningkat sebesar $11,52 \%$. Pada tahun 2009, jumlah penduduk yang berada di bawah garis kemiskinan bertambah sekitar $13,83 \%$ atau menjadi 71.564 jiwa dibandingkan dengan tahun 2007 Sementara tingkat pengangguran terbuka hanya turun sekitar 7,73\% dari keseluruhan angkatan kerja pada tahun 2009 atau dari 6.007 orang pada tahun 2007 menjadi 4.074 orang pada 2009. Seharusnya Dengan pertumbuhan ekonomi yang tinggi dapat mengurangi jumlah penduduk miskin dan pengangguran.

Tabel 1

Realisasi Angkatan Kerja dan

Penduduk Miskin Makassar, 2006-2009

\begin{tabular}{|c|c|c|c|c|c|}
\hline \multirow{2}{*}{$\begin{array}{l}\text { N } \\
\text { o. }\end{array}$} & \multirow{2}{*}{$\begin{array}{c}\text { Indikator } \\
\text { Struktur } \\
\text { Ekonomi }\end{array}$} & \multicolumn{4}{|c|}{ Realisasi } \\
\hline & & 2006 & 2007 & 2008 & 2009 \\
\hline I. & $\begin{array}{l}\text { Angkatan } \\
\text { Kerja } \\
\text { dan } \\
\text { Bukan } \\
\text { Angkatan } \\
\text { Kerja } \\
\text { (Orang) }\end{array}$ & 86.095 & 87.228 & 92.104 & 93.492 \\
\hline \multirow[t]{3}{*}{1.} & $\begin{array}{l}\text { Angkatan } \\
\text { Kerja } \\
\text { (Orang) }\end{array}$ & 54.629 & 51.701 & 52.632 & 52.686 \\
\hline & Bekerja & 46.741 & 45.694 & 47.205 & 48.612 \\
\hline & $\begin{array}{l}\text { Mencari } \\
\text { Pekerjaan }\end{array}$ & 7.888 & 6.007 & 5.427 & 4.074 \\
\hline \multirow[t]{3}{*}{2.} & $\begin{array}{l}\text { Bukan } \\
\text { Angkatan } \\
\text { Kerja } \\
\text { (Orang) }\end{array}$ & 31.466 & 35.527 & 39.472 & 40.806 \\
\hline & Sekolah & 11.634 & 15.366 & 18.358 & 19.025 \\
\hline & Lainnya & 19.832 & 20.161 & 21.114 & 21.781 \\
\hline \multirow[t]{2}{*}{3.} & $\begin{array}{l}\text { Pengangg } \\
\text { uran } \\
\text { Terbuka } \\
(\%)\end{array}$ & 14,44 & 11,62 & 10,31 & 7,73 \\
\hline & $\begin{array}{l}\text { Jumlah } \\
\text { (Orang) }\end{array}$ & 7.888 & 6.007 & 5.427 & 4.074 \\
\hline II & \multicolumn{5}{|c|}{ Penduduk Miskin (Orang) } \\
\hline \multirow[t]{2}{*}{1.} & $\begin{array}{l}\text { Penduduk } \\
\text { dibawah } \\
\text { Garis } \\
\text { Kemiskina } \\
n\end{array}$ & 49.786 & 56.034 & 63.3580 & 71.564 \\
\hline & $\begin{array}{l}\text { Persentase } \\
\text { Terhadap } \\
\text { Penduduk }\end{array}$ & 14,35 & 12,55 & 13,07 & 12,95 \\
\hline \multirow[t]{2}{*}{2.} & $\begin{array}{l}\text { Penduduk } \\
\text { Miskin }\end{array}$ & 29.540 & 32.432 & 38.232 & 46.862 \\
\hline & $\begin{array}{l}\text { Persentase } \\
\text { Terhadap } \\
\text { Penduduk }\end{array}$ & 10,85 & 9,79 & 17,89 & 22,57 \\
\hline 3. & $\begin{array}{l}\text { Penduduk } \\
\text { dibawah } \\
\text { Garis }\end{array}$ & 79.326 & 88.466 & 101.590 & 118.426 \\
\hline
\end{tabular}




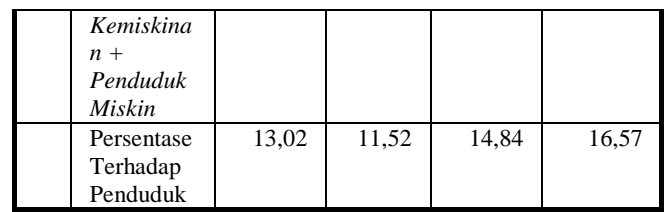

Sumber : RKPD Kota Makassar Tahun 2010

Kedua, sektor non-tradeable selama beberapa tahun terakhir justru bergerak cepat dan menjadi sumber terpenting pertumbuhan ekonomi. Dalam peta penyerapan tenaga kerja, sektor telekomunikasi, konstruksi, dan keuangan terus meningkat. Dengan pertumbuhan ekonomi yang konsisten di atas rata-rata pertumbuhan ekonomi nasional, maka sektor tersebut menikmati kemakmuran ekonomi yang lebih besar ketimbang sektor lainnya. Implikasinya, tenaga kerja yang terlibat di dalamnya memeroleh penghasilan yang lebih besar. Fakta ini menimbulkan munculnya intensitas ketimpangan pendapatan yang lebih besar antarsektor ekonomi (juga ketimpangan pendapatan antarpelaku dan antarwilayah). Tenaga kerja menumpuk di tradeable sector. Deskripsi ini dengan mudah menerbitkan kesimpulan bahwa selama sektor riil terjebak dalam pertumbuhan rendah, maka masalah kemiskinan dan pengangguran sulit diatasi.

Dalam konteks Makassar, misalnya pada tahun 2007, pertumbuhan sektor pertanian, peternakan, kehutanan dan perikanan (sub-sektor tanaman pangan, sub-sektor tanaman perkebunan, sub-sektor peternakan dan hasilnya serta sub-sektor perikanan) mencapai 11,93\% dibandingkan dengan tahun 2006 dengan kontribusi pada PDRB sebesar 16,96\% atau Rp. 212,762 milyar. Secara parsial, sub-sektor tanaman pangan, sub-sektor tanaman perkebunan dan sub-sektor peternakan dan hasilnya sebesar $31,90 \%$ dan sub-sektor perikanan sebesar $68,10 \%$. Dari segi nilai perdagangan antar pulau, sektor pertanian, peternakan, kehutanan dan perikanan memberikan kontribusi sebesar Rp. 76,399 milyar atau 92,94\% dari keseluruhan nilai total perdagangan antar pulau. Sementara, dalam kaitannya dengan penyerapan lapangan kerja, sektor pertanian, peternakan, kehutanan dan perikanan mampu menyerap sebanyak 9.951 orang tenaga kerja atau $21,78 \%$ dari keseluruhan angkatan kerja yang bekerja pada tahun 2007. Ini berarti tumbuhnya kecil, shared atau kontribusinya dalam struktur PDRB ekonomi kecil, sedangkan sharednya pada lapangan kerja masih tinggi yang berarti nilainya semakin kecil. Pendapatan di sektor ini atau harga ekonomian petani kecil berlawanan dengan pendapatan masyarakat di sektor non tradable yang membesar. Sebagaimana dijelaskan di atas menimbulkan ketimpangan pendapatan yang lebih besar antarsektor ekonomi (juga ketimpangan pendapatan antarpelaku dan antarwilayah). Tanpa disadari, ketimpangan pertumbuhan ekonomi antara sektor tradeable dan nontradeable bakal menjadi sumber persoalan ekonomi, bahkan menjalar ke masalah sosial dan politik dikemudian hari. Berikut tabel struktur PDRB Kota Makassar 2006 2009 :

Tabel 2

Struktur PDRB Kota Makassar

\begin{tabular}{|r|l|r|r|r|r|}
\hline \multicolumn{5}{|c|}{ Struktur PDRB (\%) } \\
\hline 1. & Pertanian & 17,89 & 16,96 & 18,53 & 18,59 \\
\hline 2. & $\begin{array}{l}\text { Pertambangan dan } \\
\text { Penggalian }\end{array}$ & 0,50 & 0,41 & 0,52 & 0,52 \\
\hline 3. & Industri Pengolahan & 2,52 & 2,58 & 2,09 & 1,92 \\
\hline 4. & $\begin{array}{l}\text { Listrik, Gas dan Air } \\
\text { Bersih }\end{array}$ & 0,96 & 1,21 & 1,03 & 1,07 \\
\hline 5. & Konstruksi/Bangun & 14,73 & 15,50 & 14,27 & 13,97 \\
\hline 6. & $\begin{array}{l}\text { Perdagangan, Hotel } \\
\text { dan Restoran }\end{array}$ & 23,46 & 24,24 & 22,64 & 22,38 \\
\hline 7. & $\begin{array}{l}\text { Pengangkutan dan } \\
\text { Komunikasi }\end{array}$ & 10,70 & 11,18 & 12,90 & 13,60 \\
\hline 8. & $\begin{array}{l}\text { Keuangan, } \\
\text { Persewaan Bangunan } \\
\text { dan Jasa Perusahaan }\end{array}$ & 6,22 & 5,99 & 7,58 & 8,46 \\
\hline 9. & Jasa-Jasa & 23,02 & 21,91 & 20,42 & 19,50 \\
\hline
\end{tabular}

Sumber : RKPD Kota Makassar Tahun 2010

Ketiga, pertumbuhan ekonomi tak berkualitas sebagaimana dijelaskan oleh Ahmad Erani Yustika salahsatunya juga diperlihatkan pada informalisasi ekonomi. Salah satu implikasi dari strategi pembangunan dapat dilihat dari gejala informalisasi ekonomi. Maksudnya, kegiatan ekonomi disesaki dengan pelaku sektor informal, termasuk tenaga kerja yang terlibat di dalamnya. Pada 2009, tenaga kerja yang masuk ke sektor informal hampir mencapai $65 \%$ dari total 
angkatan kerja, padahal pada 2008 jumlahnya baru mencapai $61 \%$. Realitas ini berbahaya, karena pada saat modernisasi dan transformasi struktural ekonomi telah berjalan, tapi pelaku ekonomi yang terlibat dalam sektor informal justru bertambah. Dalam konteks

Makassar informalisasi ekonomi ini ditunjukkan oleh perkembangan Kredit UMKM. Usaha Mikro, Kecil dan Menengah (UMKM) merupakan sektor usaha yang menjadi sokoguru dalam perekonomian Kota Makassar dengan potensinya yang sangat besar. Kinerja penyaluran KUMKM di Kota Makassar menunjukkan pertumbuhan yang positif selama kurun waktu 20062007 dengan rata-rata pertumbuhan sekitar $27 \%$ per tahun. Pada tahun 2006, besarnya KUMKM yang berhasil disalurkan adalah sebanyak Rp. 266,967 milyar atau meningkat sebesar $17,30 \%$ dibandingkan tahun 2005 atau 99,97\% dari keselurahan kredit yang berhasil disalurkan di Kota Makassar. Dengan makin membaiknya perkembangan UMKM, maka pada tahun 2007 KUMKM yang disalurkan oleh perbankan di Kota Makassar meningkat sekitar 36,92\% atau naik menjadi Rp. 365,519 milyar dengan pangsa sebesar $97,13 \%$ dari keseluruhan kredit yang disalurkan. Pada tahun 2008, kucuran dana untuk KUMKM akan terus meningkat dengan nilai sebesar Rp. 473,795 milyar atau $95,13 \%$ dari keselurahan kredit yang berhasil disalurkan di Kota Makassar pada tahun tersebut.

Menurut pengelompokkannya, KUMKM pada tahun 2006 lebih banyak diporsikan untuk usaha mikro (kredit sampai dengan nilai Rp. 50 juta), yaitu sekitar 42,84\% atau sebesar Rp. 114,368 milyar, sementara untuk usaha kecil (kredit di atas Rp. 50 juta sampai dengan Rp. 500 juta) dan usaha menengah (kredit di atas Rp. 500 juta sampai dengan Rp. 5 milyar) masing-masing hanya sekitar $29,10 \%$ dan $28,15 \%$. Pada tahun 2007, meskipun porsi kredit untuk usaha mikro tetap dominan $(36,91 \%)$, akan tetapi porsi kredit untuk usaha kecil naik menjadi 34,52\%. Sementara porsi kredit untuk usaha menengah relatif sama dengan tahun 2006, yaitu $28,57 \%$.

Pada tahun 2006 proporsi KUMKM yang disalurkan digunakan untuk konsumsi sebesar Rp. 128,304 milyar $(48,06 \%)$ dan untuk modal kerja sebesar Rp. 122,293 milyar $(45,81 \%)$ dan sisanya sekitar $6,13 \%$ digunakan untuk investasi. Meskipun proporsi KUMKM untuk konsumsi menurun hanya sebesar $41,20 \%$ atau $\mathrm{Rp}$. 150,583 milyar pada tahun 2007, akan tetapi alokasi untuk investasi justru menurun, yaitu hanya $5,26 \%$ atau hanya Rp. 19,209 milyar. Pada sisi lain, alokasi KUMKM yang diperuntukkan untuk modal kerja meningkat menjadi 53,55\% atau menjadi Rp. 195,727 milyar. Pada tahun 2008, komposisi penyaluran KUMKM untuk modal kerja terus meningkat, sementara alokasi untuk konsumsi dan investasi terus menurun.

Berdasarkan sektor ekonomi, KUMKM 2006 pada umumnya disalurkan pada sektor lainnya yang mencapai Rp. 128,583 milyar atau $48,11 \%$ dari keseluruhan total KUMKM pada tahun 2006. Sektor perdagangan dengan pangsa sebesar Rp. 102,778 milyar atau 38,50\% menjadikan sektor ini sebagai sektor terbesar kedua dalam penyaluran kredit di Kota Makassar pada tahun 2006. Sementara, sektor jasa-jasa, sektor pertanian dan sektor perindustrian mempunyai pangsa sebesar 5,22\%, 4,58\% dan 3,58\%. Pada 2007, KUMKM yang disalurkan pada sektor perdagangan menempati urutan pertama dengan nilai kredit sebesar Rp. 165,084 atau 45,16\% dan sektor lain-lain menempati urutan kedua dengan persentase sebesar $41,20 \%$.

Keempat, sebagai faktor pendukung adalah lemahnya APBD dalam menciptakan kesempatan kerja dengan kata lain APBD tidak bisa banyak diharapkan. Secara konseptual APBD untuk seluruh wilayah di Indonesia masih sangat tergantung dari dana transfer pusat (APBN), khususnya pada level kabupaten/ 
kota. Pendapatan Asli daerah (PAD) Kota Makassar hanya memberikan kontribusi sebesar 3,45\%, 4,36\% dan 4,22\% atau Rp. 8,963 milyar, Rp. 13,286 milyar dan Rp. 14,167 milyar selama kurun waktu 20062008 bagi APBD.

Jika aloksi APBD dibedah, di mana dana transfer merupakan komponen terbesar penumbang APBD, maka akan dijumpai beberapa realitas berikut. Porsi APBD untuk pegawai mengalami keanaikan dari waktu ke waktu. Tercatat beberapa daerah kabupaten/kota yang belanja pegawainya bisa dianggap mengerikan, misalnya Lumajang (83\%), Karanganyar (75\%), Ambon (73\%), Simalungun (72\%), Agam (72\%), Kuningan (71\%), dan Palu (71\%). Sedangkan Kota Makassar $64 \%$. Dengan deimikian hampir bisa dipastikan tidak dapat menggerakkan pembangunan daerah, karena APBD habis untuk aparat (bukan rakyat). Fungsi anggaran belanja sebagai instrumen stabilisasi, alokasi, dan distribusi praktis telah lumpuh.

Celakanya, realisasi belanja modal yang sudah sangat kecil (karena terpotong belanja pegawai) penyerapannya rendah, seringkali kurang dari 90\%. Pada tahun yang sama, penyerapan belanja pegawai melebihi $90,0 \%$. Di sini menunjukkan kapasitas birokrasi di daerah tidak cukup cakap mengelola program yang sudah direncanakan sebelumnya. Di sisi lain, daerah-daerah yang memiliki kapasitas fiskal terbatas terpaksa harus membikin anggaran defisit untuk membiayai kebutuhannya, khususnya belanja pegawai.

Melihat fenomena ini seakan sesuai dengan pendapat Adam Smith dan David Ricardo yang merupakan tokoh pendekatan teori Ekonomi Politik Klasik. Dalam teori Ekonomi Politik Klasik dinyatakan bahwa pasar memiliki kemampuan untuk mengelola dirinya sendiri. Bahkan para ekonom klasik ini memandang perekonomian sebagai sebuah sistem yang secara prinsip terpisah dari politik dan rumah tangga. Dalam teori klasik maupun neo klasik menganggap permintaan dan penawaran terhadap tenaga kerja selalu seimbang karena harga-harga fleksibel dimana ini bertentangan dengan Keynes bahwa pasar tenaga kerja jauh dari seimbang, karena upah tidak pernah fleksibel, sehingga permitaan dan penawaran hampir tidak pernah seimbang sehingga pengangguran sering terjadi. Pengangguran bisa terjadi terus menerus.

Janji teori neoklasik yang mengatakan perekonomian akan tetap mengalami tingkat kesempatan kerja penuh dan kapasitas alat-alat modal tetap digunakan sepenuhnya dari masa kemasa tidak terbukti dalam kasus nasional dan Kota Makassar. Pendapat Dudley Seers semestinya diperhatikan, Ia mengemukakan bahwa tolak ukur pembangunan ekonomi tidak saja pada peningkatan pendapatan perkapita tetapi hendaknya juga disertai oleh baiknya distribusi pendapatan, menurunnya angka kemiskinan dan pengangguran.

\section{Perlunya Kebijakan Pemerintah Kota Makassar terhadap Perluasan Kesempatan Kerja dalam mendorong Peningkatan Produktivitas Wilayah}

Menurut Teori klasik maupun neo klasik, dalam usaha menciptakan lapangan kerja, pemerintah secara aktif menyusun kebijakan makro yang bertujuan mencari sumber-sumber pertumbuhan ekonomi baru. Pada masa lalu, pertumbuhan ekonomi bersumber pada upah murah dan sumber daya alam. Dua sumber pertumbuhan ini sudah berkurang potensinya dan sekarang atau ke depan perlu mencari sumber pertumbuhan ekonomi baru dengan menggunakan jalur investasi, teknologi maupun perdagangan (ekspor-impor) melalui berkembangnya sektor swasta. Untuk mencapai tujuan ini pemerintah nasional perlu memasukkan kebijakan ketenagakerjaan sebagai bagian dalam pembuatan kebijakan ekonomi makro sejajar dengan kebijakan ekonomi makro lain atau secara ekplisit tergambar dalam rencana pertumbuhan ekonomi, 
pengendalian inflasi dan neraca pembayaran. (Ahmad Erani Yustika :2009)

1. Dari sisi makro, penciptaan lapangan kerja akan lebih kondusif bila: (a) nilai tukar dan tingkat suku bunga stabil dan kompetitif, dan (b) reformasi bidang keuangan dan perbankan dilanjutkan agar fungsi intermediasi bank dapat mendorong berkembangnya sektor rill.

2. Dalam pengambilan keputusan tentang kebijakan makro, perlu diikut sertakan ahli-ahli ekonomi ketenagakerjaan yang kompeten. Masalah ketenagakerjaan sebaiknya dimasukkan menjadi bagian dari kebijakan ekonomi makro. Hal ini dilakukan agar kebijakan ekonomi makro sejalan dengan kebijakan ketenagakerjaan. Kebijakan ketenagakerjaan seyogyanya tidak terpaku pada masalah kesejahteraan pekerja formal saja, tetapi juga menyiasati kebijakan makro agar pekerja di lapangan kerja informal, dimana pekerja banyak terkonsentrasi pada usaha menengah, kecil dan mikro, dapat merasakan manfaatnya.

3. Kebijakan pokok yang diperlukan untuk mendukung penciptaan kesempatan kerja adalah:

a. Penyempurnaan regulasi yang berkaitan dengan aturan main ketenagakerjaan harus dapat menciptakan pasar kerja yang fleksibel. Pada tenaga kerja Indonesia yang merupakan pasar dengan lapangan kerja informal $70 \%$ dari seluruh lapangan kerja, serta jumlah angkatan kerja yang sangat besar (sekitar 100 juta) dimana kebanyakan angkatan kerja (sekitar 55\%) adalah lulusan SD dan SD ke bawah, ditambah lagi jumlah penganggur terbuka yang cukup besar maka kebijakan pasar kerja yang fleksibel sangat dibutuhkan. Dengan makin tidak fleksibelnya pasar kerja akan berakibat pada tingginya tingkat pengangguran usia muda dan berketerampilan rendah. Undang- undang No 13 Tahun 2003 tentang ketenagakerjaan secara umum memberikan sumbangan yang sangat positif terhadap berjalannya pasar kerja di Indonesia. Undangundang yang baru ini memperlihatkan konsensus dari berbagai pihak tekait mengenai isu-isu yang sebelumnya sangat menimbulkan pertentangan. Undang-undang yang baru ini juga sejalan dengan berbagai konvensi ILO yang telah diratifikasi. Hal mendasar yang dicantumkan dalam Undang-undang tersebut adalah ditetapkannya aturan main mengenai representasi pekerja dalam rangka proses perundingan kolektif. Namun demikian, ada beberapa bagian yang apabila dijalankan secara kaku justru akan mengurangi fleksibilitas pasar kerja. Kuncinya, aturan main pasar kerja tidak seharusnya menimbulkan distorsi yang besar terhap keputusan persahaan mengenai investasi dan penggunaan tenag kerja. Pengaturan yang berlebihan mengenai uapah minimum , pekerja kontrak, serta PHK berptensi untuk mengurangi fleksibilitas pasar kerja.

b. Penyempurnaan kebijakann dari sisi permintaan (demand side). Kebijakan ini dimaksudkan untuk meningkatkan investasi dan penguatan pada kegiatan ekonomi yang sudah ada. Kebijakan perluasan kesempatan melalui investasi dikaitkan pula dengan kebijakan pengembangan UKM. Selain kebijakan yang berkait langsung dengan pasar kerja, pencintaan lapangan kerja sangat ditentukan oleh kebijakan lain. Seperti telah disinggung sebelumnya keadaan tenaga kerja kita yang mayoritas unskiiled. 
Dalam Konteks Makassar, sektor non-tradeable selama beberapa tahun terakhir bergerak cepat dan menjadi sumber terpenting pertumbuhan ekonomi. Dalam struktur ekonomi dan peta penyerapan tenaga kerja, sektor telekomunikasi, konstruksi, dan keuangan terus meningkat. Ke depan Sektor tradable misalnya industry atau manufaktur perlu dikembangkan sehingga bisa mengurangi pengangguran dan informalisasi ekonomi.

Rencana pemerintah Makassar dorongan akan diberikan pada peningkatan investasi, pengembangan industri, ekspor dan pariwisata perlu didukung. Investasi atau penanaman modal dalam negeri harus ditingkatkan. Peningkatan pada tahun 2007 investasi dari Rp. 8 milyar dengan jumlah proyek sebanyak 2 menjadi Rp. 1.212 milyar dengan 9 proyek perlu ditiru dan ditingkatkan ke depan. Hal ini sekaligus menunjukkan bahwa keterlibatan swasta dalam pembiayaan pembangunan di Kota Makassar perlu ditingkatkan, karena seperti data di atas APBD tidak bisa banyak diharapkan. Pada tahun 2007, industri non-migas tumbuh sebesar $11,01 \%$ atau meningkat dibandingkan dengan keadaan tahun 2006 yang hanya mencapai $6,26 \%$. Meskipun demikian, kontribusi sektor industri dalam hal ini sub-sektor industri non-migas masih relatif rendah dalam pembentukkan PDRB Kota Makassar, yaitu hanya sekitar $2,58 \%$ atau Rp. 32,42 milyar pada tahun 2007. Hal ini cukup beralasan, karena sektor industri Kota Makassar pada umumnya adalah industri skala kecil dan menengah.

Sampai dengan tahun 2007, Kota Makassar lebih banyak memposisikan diri sebagai pusat perekonomian atau perdagangan bagi kawasan-kawasan belakangnya. Oleh karena itu, mobilitas arus masuk barang (impor) antar pulau Kota Makassar memang tinggi. Meskipun demikian, hal tersebut belum menjadikan Kota Makassar sebagai kota dagang yang setara atau minimal mendekati peranan Kota Kendari atau Makassar.
Jadi, pengembangan ekonomi lokal ke depan perlu di dorong untuk menurunkan tingkat pengangguran yang mulai menunjukkan kecenderungan menurun dan mengurangi jumlah penduduk miskin yang besar dengan mendorong kualitas pertumbuhan ekonomi sekaligus menghindari informalisasi ekonomi. Industri yang berbasis sumberdaya lokal dan wilayah hinterland bisa diintensifkan seperti industri perikanan dan perkebunan seperti Jambumete.

\section{SIMPULAN}

Terdapat beberapa fakta yang menunjukkan pertumbuhan ekonomi Kota Makassar 2005 - 2009 adalah pertumbuhan tak berkualitas. Pertama, Selama kurun waktu 2005-2009, laju pertumbuhan ekonomi Kota Makassar ratarata $7,70 \%$, akan tetapi hal tersebut belum mampu mendorong terbukanya kesempatan kerja baru secara signifikan. Kedua, sektor non-tradeable selama beberapa tahun terakhir justru bergerak cepat dan menjadi sumber terpenting pertumbuhan ekonomi. Ketiga, diperlihatkan pada informalisasi ekonomi. Maksudnya, kegiatan ekonomi disesaki dengan pelaku sektor informal, termasuk tenaga kerja yang terlibat di dalamnya. Keempat, sebagai faktor pendukung adalah lemahnya APBD dalam menciptakan kesempatan kerja dengan kata lain APBD tidak bisa banyak diharapkan, masih sangat tergantung dari dana transfer pusat (APBN), khususnya pada level kabupaten/ kota. Pendapatan Asli daerah (PAD) Kota Makassar hanya memberikan kontribusi sebesar 3,45\%, 4,36\% dan 4,22\% atau Rp. 8,963 milyar, Rp. 13,286 milyar dan Rp. 14,167 milyar selama kurun waktu 2006-2008 bagi APBD. Janji teori neoklasik yang mengatakan perekonomian akan tetap mengalami tingkat kesempatan kerja penuh dan kapasitas alat-alat modal tetap digunakan sepenuhnya dari masa kemasa tidak 
terbukti dalam kasus nasional dan Kota Makassar.

Kebijakan ketenagakerjaan seyogyanya tidak terpaku pada masalah kesejahteraan pekerja formal saja, tetapi juga menyiasati kebijakan makro agar pekerja di lapangan kerja informal, dimana pekerja banyak terkonsentrasi pada usaha menengah, kecil dan mikro, dapat merasakan manfaatnya. Kebijakan yang diperlukan untuk mendukung penciptaan kesempatan kerja adalah penyempurnaan regulasi yang berkaitan dengan aturan main ketenagakerjaan.harus dapat menciptakan pasar kerja yang fleksibel. Penyempurnaan kebijakann dari sisi permintaan (demand side). Kebijakan ini dimaksudkan untuk meningkatkan investasi dan penguatan pada kegiatan ekonomi yang sudah ada. Dalam Konteks Makassar, sektor non-tradeable selama beberapa tahun terakhir bergerak cepat dan menjadi sumber terpenting pertumbuhan ekonomi. Dalam struktur ekonomi dan peta penyerapan tenaga kerja, sektor telekomunikasi, konstruksi, dan keuangan terus meningkat. Ke depan Sektor tradable misalnya industry atau manufaktur perlu dikembangkan sehingga bisa mengurangi pengangguran dan informalisasi ekonomi.

\section{DAFTAR PUSTAKA}

Badan Perencana Pembangunan Daerah Kota Makassar. RKPD Kota Makassar Tahun 2010

Badan Perencana Pembangunan Daerah Kota Makassar. RKPD Kota Makassar Tahun 2008

Badan Perencana Pembangunan Daerah Kota Makassar. RPJMD Kota Makassar 2008 -2013

Badan Pusat Statistik Kota Makassar, Kota Makassar dalam Angka, Beberapa Edisi.diolah

Caporaso \& Levine, 2008, Terjemahan, Teori-teori Ekonomi Politik, Pustaka Pelajar, Jogjakarta.
Deliarnov, Ekonomi Politik, Mencakup Berbagai Teori dan Konsep yang Komprehensif, 2006, Erlangga, Jakarta.

Yustika, Ahmad Erani, Ekonomi Politik, Kajian Teoritis dan Kajian Empiris. 2009, Pustaka Pelajar, Jogjakarta.

Yustika Ahmad Erani, 2010. Pertumbuhan Tanpa Koma. Jawa Pos 11 Agustus 2010.

Yustika Ahmad Erani, 2011. Pembusukkan Pembangunan Ekonomi. Jawa Pos 16 Mei 2011 